\title{
Agenda-setting in the Common Security and Defence Policy: An Institutionalist Perspective
}

Citation for published version (APA):

Dijkstra, H. (2012). Agenda-setting in the Common Security and Defence Policy: An Institutionalist Perspective. Cooperation and Conflict, 47(4), 454-472. https://doi.org/10.1177/0010836712462772

Document status and date:

Published: 01/12/2012

DOI:

10.1177/0010836712462772

Document Version:

Accepted author manuscript (Peer reviewed / editorial board version)

\section{Document license:}

Unspecified

\section{Please check the document version of this publication:}

- A submitted manuscript is the version of the article upon submission and before peer-review. There can be important differences between the submitted version and the official published version of record.

People interested in the research are advised to contact the author for the final version of the publication, or visit the DOI to the publisher's website.

- The final author version and the galley proof are versions of the publication after peer review.

- The final published version features the final layout of the paper including the volume, issue and page numbers.

Link to publication

\footnotetext{
General rights rights.

- You may freely distribute the URL identifying the publication in the public portal. please follow below link for the End User Agreement:

www.umlib.nl/taverne-license

Take down policy

If you believe that this document breaches copyright please contact us at:

repository@maastrichtuniversity.nl

providing details and we will investigate your claim.
}

Copyright and moral rights for the publications made accessible in the public portal are retained by the authors and/or other copyright owners and it is a condition of accessing publications that users recognise and abide by the legal requirements associated with these

- Users may download and print one copy of any publication from the public portal for the purpose of private study or research.

- You may not further distribute the material or use it for any profit-making activity or commercial gain

If the publication is distributed under the terms of Article $25 \mathrm{fa}$ of the Dutch Copyright Act, indicated by the "Taverne" license above, 


\title{
Agenda-Setting in the Common Security and Defence Policy: An Institutionalist Perspective
}

\author{
Hylke Dijkstra \\ Accepted version of an article published in Cooperation and Conflict 47(4), 2013, pp. 454-472 \\ DOI: $10.1177 / 0010836712462772$
}

\begin{abstract}
The European Union has launched an impressive number of crisis management missions since its Common Security and Defence Policy became operational in 2003. This article analyses the agenda-setting phase of these civilian and military operations in order to explain why the EU has sent troops, policemen, judges, prosecutors and monitors across three continents. It presents an institutionalist perspective and argues that the former High Representative Javier Solana and his officials have been instrumental in putting various operations on the agenda. They have employed deliberate agenda-setting strategies, such as venue-shopping, conflict expansion and issue framing, to further their bureaucratic interest of launching new missions. Solana and his officials had the ability to affect the agenda-setting process due to their pivotal position in policy-making. This gave them with superior information on the state-of-play, an early mover advantage as well as strong international networks. The article provides empirical evidence from the crisis management missions in Aceh, Bosnia, Chad and Kosovo. It concludes with the changes to the Common Security and Defence Policy after the Treaty of Lisbon.
\end{abstract}

Keywords. Agenda-setting; CSDP; European Union; institutionalism, Javier Solana.

\section{INTRODUCTION}

Foreign policy officials in the European Union (EU) like to pride themselves with the twenty-eight civilian and military operations that were launched since the Common Security and Defence Policy (CSDP) became operational in 2003. There is reason for this sense of achievement. After decades of limited developments in foreign policy, few observers predicted at the turn of the twenty-first century that the EU would sent troops, policemen, monitors, judges, prosecutors and customs guards on missions across three continents. These operations have contributed to stability and security, the implementation of peace agreements and local capacity building in many of the world's trouble spots. While the number and great diversity of CSDP operations is impressive, the question remains why the EU has launched all these missions. Few were a direct consequence of strategic demands from the international system and therefore national interest (Waltz 1979), even fewer resulted from normative considerations (Manners 2002).

This article makes a contribution to these debates by presenting an institutional perspective on agenda-setting in the CSDP. It uses four case studies to show that Javier Solana, the former High 
Representative for the Common Foreign and Security Policy (CFSP) (1999-2009), and his civil servants in the Council Secretariat were instrumental in putting several missions high on the EU agenda. ${ }^{1}$ They had strong bureaucratic interests in establishing CSDP as an EU policy. Launching operations was their means. Every time a window of opportunity passed by, they tried to seize the moment and pleaded for a new mission. Solana and his officials were often successful due to their central position in policy-making and their international networks. They were much earlier involved in the planning of operations than the majority of the member states. This allowed them to construct faits accomplis. It also gave them the opportunity to frame operations in terms that were palatable to the member states and to set some of the important parameters of the CSDP missions.

In addition to the debate on why the EU has deployed so many CSDP operations, this article speaks to several literatures. First, it makes a contribution to the overall agenda-setting literature in the EU (e.g. Tallberg 2003; Princen 2007, 2009, 2011). By broadening the empirical domain to include the CSDP as well, this article finds that the external mobilisation of like-minded actors is more important than typically recognised. Second, it contributes to our understanding of the autonomous role of international organizations (e.g. Barnett and Finnemore 1999, 2004; Pollack 2003; Hawkins et al. 2006; Biermann and Siebenhüner 2009). In addition to political leadership, this article makes clear that a central position in policy-making in-between the member states and third actors helps international organizations to shape outcomes.

This article starts by explaining how Solana and his officials could affect the agenda-setting process in CSDP. It shortly discusses the agenda-setting literature in the EU and then zooms in on the specific agenda-setting resources of Solana and his officials. The article subsequently traces the agenda-setting process of the military operation in Bosnia (Althea, 2004-date), the Aceh monitoring mission (AMM, 2005-2006), the military operation in Chad and the Central African Republic (EUFOR, 2007-2008), and the rule of law mission in Kosovo (EULEX, 2008-date). These were four of the most important CSDP operations. They vary in terms of issues, place and time. ${ }^{2}$ The article uses data from official documents and 105 semi-structured elite interviews with officials from the member states, the EU institutions and international organizations. These sources are complemented by newspaper articles and secondary literature.

\section{AGENDA-SETTING AND EU OFFICIALS}

\section{Agenda-setting in the European Union}

Agenda-setting in the EU is best seen as a process in which different actors try to put and keep their issues high on the agenda (e.g. Princen 2007; Tallberg 2003). There is a difference, in this respect, between formal and informal agenda-setting (Pollack 1997, 2003). The former refers to the agendasetting powers of, for example, the European Commission, which can use its exclusive right of initiative to its advantage in most areas. Many other EU actors may, however, informally influence the agenda-setting process. They have the ability to affect how issues are framed and whether issues are salient. Peters (2001) notes that the institutional setting in the EU, in particular, allows for many points of agenda access. This makes it important to analyse the role of non-formal power holders in informal agenda-setting. These include lobbyists, think tanks, the six-monthly rotating Presidency as well as Solana and his civil servants.

Contrary to popular beliefs, the process of agenda-setting is not necessarily about having bright ideas. Kingdon (1984: 71) notes that "ideas can come from anywhere". The trick for EU

\footnotetext{
Catherine Ashton succeeded Solana as the High Representative in 2009. The crisis management services of the Council Secretariat were transferred to the European External Action Service in 2010-2011, but largely stayed the same. The conclusion of this article discusses what the implications of the Lisbon Treaty are for the agenda-setting of CSDP.

2 Althea and EUFOR are military missions, while AMM and EULEX are civilian missions; Althea and EULEX are in Europe, while AMM and EUFOR took place outside Europe; Althea and AMM were relatively early missions, while EUFOR and EULEX were took place later.
} 
actors is to pick-and-choose those ideas that benefit their interests, raise awareness for their issues and rally support from other actors. Importantly, they cannot pick any idea as some ideas might be completely unrealistic given the preferences of formal power holders. Yet by promoting those ideas that benefit their cause, they can affect the outcome of the policy process in their favour. When it comes to raising awareness and rallying support, there are various strategies that EU actors can employ. The agenda-setting literature suggests venue-shopping, conflict expansion, and the issue framing (e.g. Schattschneider 1960; Cobb, Ross and Ross 1976; Baumgartner and Jones 1991). These strategies aim at getting a majority behind the issue before decision-making takes place (for the CSDP decision phase, see Howorth (2012) in this issue).

The starting point for successful agenda-setting is choosing the venue (e.g. a working group, fact-finding mission, or Council formation; Parliament; European Council; another international organization) that is most receptive to the issue. In situations of bounded rationality and a lack of full information, it may not always be clear which venue is the most appropriate. Venue-shopping, whereby actors test the receptiveness of different venues, is an often-used strategy in this respect (Baumgartner and Jones 1991; Kingdon 1984). Building on Cobb et al. (1976), Princen and Rhinard (2006) distinguish between a political and administrative route to agenda-setting. The political route includes top-down pressure by the European Council. The administrative route, on the other hand, is a bottom-up process with the incremental formulation of proposals. They present these as idealtypes and note that a combination may be relevant. What seems powerful is the ability of EU actors to alternate between political and administrative venues. If EU actors can push for their issues in both arenas, they are in a good position to affect the agenda-setting process.

Strategically raising issues in the most receptive venues is often not enough. One also needs to get other actors on board. Schattschneider (1960) suggested to enlarge the group of involved actors with those that support the issue. He calls this conflict expansion, as by expanding the group with like-minded actors the balance between proponents and opponents shifts. One method is to mobilize the outside public, while other actors rely on inside lobbying (Cobb et al. 1976). Princen (2007) notes that mobilization ('outside lobbying') is less attractive within the EU due to a lack of a genuine pan-European public space. In the area of foreign policy, however, involving third parties (e.g. United States [US], United Nations [UN]) and raising external expectations about EU actions (Hill 1993) can clearly affect the agenda-setting process. It allows for the construction of faits accomplis. International networks are, in this respect, an important asset for EU actors. With regard to inside lobbying, finding like-minded member states and presenting a united front is definitely beneficial if the opposing actors are more fragmented.

When rallying support of other actors, the framing of issues is also important (Baumgartner and Jones 1991). Most EU member states, for example, prefer a humanitarian intervention over a post-colonial stabilization effort. By framing an operation as a 'test-case' for CSDP, the contents of the actual mission becomes less important. Issue framing thus affects, in this respect, the balance between supporting and opposing actors. It is important to note that framing is not only about changing the dominant discourse. It has also consequences for the eventual policy substance. With an humanitarian frame, one should not be surprised ending up with an humanitarian mandate. There thus exists a trade-off between getting actors on board and keeping to one's true preferences. Finally, there is a clear early-mover advantage when it comes to framing. The broader the group of actors becomes, the more difficult it is to change the discourse. Early involvement is therefore crucial for agenda-setting.

\section{The High Representative and EU officials as agenda-setters}

According to the agenda-setting literature, actors can thus affect the EU agenda when they occupy a central position in the policy process, have international networks and can benefit from early-mover advantage. The following section stresses that Solana and his officials possessed these resources. This gave them the possibility to exert leadership in the agenda-setting phase and, as such, to make an autonomous contribution to the policy process. 
What cannot be stressed enough is the pivotal position of Solana and his officials in CSDP policy-making. Because EU officials are in charge of planning and form the liaison between crisis management operations and the discussions between member states in Brussels, they are central to anything that the EU does in the area of security and defence (Dijkstra 2008; Vanhoonacker, Dijkstra and Maurer 2010). Mérand, Hofmann, and Irondelle $(2010,2011)$ indeed show through social network analysis that Solana and the key planning departments were part of the core policy group in the CSDP network. This central position gave the EU civil servants access to various bureaucratic venues. The personal authority of Solana - as a former Spanish foreign minister and NATO Secretariat-General - gave him access to the highest political level and the capitals. These personal skills may also explain why Solana was more effective in agenda-setting than Ashton (see also conclusions).

Having such position in the policy-making process yields further advantages. It provided Solana and his officials with excellent information on the state-of-play (Beach 2005). This is a useful resource in agenda-setting, since timing and knowledge about the preferences of the member states are so crucial. The institutional position of EU civil servants also created authority, in that they are recognized as the guardian of the orthodoxy and the institutional memory of the Council (Christiansen 2002; Beach 2004; Christiansen and Vanhoonacker 2008). The relatively small size of the CSDP bureaucracies made coordination among EU officials easy compared to the member states. This allowed them to better alternate between the administrative and political venues. Further bureaucratic resources were the continuity EU officials, and the related persistence, vis-à-vis the member states and the rotating Presidency (cf. Kingdon 1984).

Solana and his officials had two other advantages over the large majority of the member states. Because of their position, they were very early involved in the CSDP policy process. This resulted in early mover advantages. It allowed them to team up with like-minded member states to present a united front and to contribute to the framing of the discourse surrounding a CSDP mission. The final advantage was in terms of international networks, which were in many case superior to those of the member states. This partly had to with the institutional position of Solana and his civil servants, which made them a focal point for third parties dealing with the EU. In addition, however, Solana and many of his senior civil servants had networks of their own in national capitals and with third parties. Once again, this personal network of Solana was a clear added value compared to his successor High Representative.

Given that Solana and his officials thus had the ability to affect agenda-setting in CSDP, it is important to identify their preferences. International agents are typically portrayed as competencemaximizer (e.g. Majone 1996; Pollack 2003; Beach 2005; Dijkstra 2010a). The article therefore assumes that they had a strong preference for more CSDP operations. This situation was particularly true in the pre-Lisbon period when having a CSDP presence on the ground provided Solana and his officials with leverage in the foreign policy turf battles with the European Commission (Cameron 2007). However, as Solana and his officials were responsible for the implementation of missions, it is also assumed that they had an interest in sensible and effective mandates. They thus did not only argue for more operations, but also tried to shape the substance of the operations.

To conclude, Solana and his civil servants possessed several resources that were useful in CSDP agenda-setting and that allowed them to potentially make an autonomous impact on agenda outcomes. Some were clearly bureaucratic resources, many of which have also been identified in the broader literature on international agents (cf. Hawkins et al. 2006; Tallberg 2006; Biermann and Siebenhüner 2009; Dijkstra 2012). Other resources were of a political nature and directly related to the person of Solana (cf. Jordan 1979; Hendrickson 2006; Chesterman 2007). Solana and his officials used a combination of these bureaucratic and political resources to increase the number of CSDP operations and to affect their contents. 


\section{AGENDA-SETTING IN CSDP: EMPIRICAL EVIDENCE}

\section{Military operation Althea in Bosnia-Herzegovina}

In December 2004, the EU took over the military mission of the North Atlantic Treaty Organization (NATO) in Bosnia-Herzegovina. This was in line with the EU taking more responsibility for the Western Balkans. The US, for example, had already reduced its contribution to the NATO mission to about 900-1,000 troops in 2004 (Bertin 2008). Moreover, the EU appointed Lord Paddy Ashdown as the first EU Special Representative to Bosnia. This was a clear signal that the EU was taking the political lead. The EU also took over parts of the UN police training mission, in what became the EU Police Mission. Finally, the Thessaloniki European Council of June 2003 confirmed that the Western Balkans had a 'European perspective'. This meant that the countries in the region were seen as potential candidates for EU membership.

After the member states established CSDP at the Cologne European Council, EU officials worked hard to create crisis management structures (1999-2002). When the 'back-office' was finally in place, there was a desire to actually deploy operations. The Western Balkans was the most-likely theatre. The EU would be able to take over ongoing NATO operations, which would require relatively little planning. After all, under the foreseen EU-NATO agreement (Berlin+), NATO's Operational Headquarters would continue to be used. Taking over a mission from NATO fitted also with the US preference to withdraw its troops from the Western Balkans and for CSDP missions to operate through NATO structures.

The idea that the EU would take over the NATO operation had been around for some time (Reichard 2006). It was, however, Solana who put the idea high on the agenda in 2002. One interviewee "clearly remembers" that the "first clear political signals came from Solana himself" (national official, 2009). Solana was eager to start a first military operation. So far the institutional development had been successful "but the proof of the pudding is in the eating" (ibid.). Woodbridge (2002: 3) confirms that a possible takeover was "aggressively pushed by the High Representative". Solana teamed up with like-minded member states (internal mobilisation). France wanted the military operations to start as well and the United Kingdom was sensitive to US concerns. France, the United Kingdom and EU officials then informally formed the core group preparing the takeover from NATO. The European Council of December 2002 subsequently "indicated [its] willingness to lead a military operation in Bosnia" (para 28-29).

There were, however, several important prerequisites before the EU could take over the NATO operation. The EU and NATO first had to agree on the use of NATO assets in the context of Berlin+. In addition, these arrangements had to be tested. It was decided that a small military operation in Macedonia would serve as a test-case. The negotiations over Berlin + , however, proved difficult (Reichard 2006; Cascone 2008). This led to delays in the handover of the operation in Macedonia (Mace 2004).

The conclusion of Berlin+ took place at the height of transatlantic tensions over Iraq, yet it seemed to have little impact. Using NATO assets was much in line with US interests (cf. Albright 1998). It increased burden-sharing and at the same time undermined the need for autonomous EU military action. The transatlantic tensions themselves, however, created a whole new rationale for autonomous action. What if NATO assets were not available for EU-led operations? Shortly after the Iraq invasion, Belgium raised the possibility of having an autonomous military headquarters separately from the NATO facilities. This made the US hostile towards CSDP. What is more, the EU launched its first French-sponsored autonomous military operation in the Congo (JuneSeptember 2003), which was viewed with great suspicion by the US (Giegerich et al. 2006).

These political developments were the main reason why the US blocked the handover at the Madrid EU-NATO summit in June 2003 (FT 2003; European Security Review 2003; Robertson, Papandreou and Solana 2003). To the EU, it came as a surprise (FT 2003). ${ }^{3}$ France, the United Kingdom and the EU officials had already tabled two planning papers, which had been adopted by

FT stands for Financial Times, IHT for International Herald Tribune, and AFP for Agence France-Presse. 
the other member states on 24 February 2003. If the United States had not blocked the takeover in Madrid, one interviewee states, "the whole preparation [for Althea] could have taken place in 2003. Theoretically, the launch of the mission could then have taken place at the end of 2003 or the beginning of 2004" (interview national official, 2009). Only after transatlantic relations improved, the takeover came back on the agenda. It eventually took place in December 2004.

The framing of the operation - and its subsequent mandate - was particularly interesting. As it was the first major EU military operation, there were considerable doubts whether the EU could do the job. It was therefore widely understood that Althea should in the first place be a continuation of the NATO operation with the same mandate, troop levels and assets (interviews with various national officials, 2009). Solana felt, however, that Althea had to do more. In a report, he noted "the opportunity that an EU-led operation would offer in terms of an integrated EU approach towards the country (notably with the presence of the EU Police Mission in [Bosnia])" (Council 2003: 9). In 2004, he went further by stating that Althea had to be a "new and distinct mission", as it would be in a "very different position from that when NATO first deployed in 1995".

Solana proposed that the operation should "have a particular focus on the fight against organised crime". The member states disagreed and insisted on continuation, which was already the established discourse. The fight against organized crime nonetheless became a supporting military task in the operations plan. Solana furthermore instructed the first force commander on the ground, Lt. General David Leakey, that the mission should be new and distinct (Leakey 2006). General Leakey accordingly decided to make the fight against organized crime the "centrepiece of his agenda" (Bertin 2008: 68). Once it became clear that the operation Althea would be established, Solana could push for his substantive interests.

To conclude, Solana and his officials played an active role in the agenda-setting of Althea. They wanted to develop the CSDP's military aspects. Deploying troops on ground was an important means. To get the member states on board, Solana teamed up with France and the United Kingdom, both of which were like-minded. They kept the handover on the table despite reluctance from the US. Solana furthermore tried to frame Althea as an operation with a comprehensive mandate, which was not fully achieve. Finally, it is important to note that, as a counterfactual, the handover from NATO was not a necessity. NATO could have been able as well to continue in Bosnia (cf. Kosovo). Agenda-setting in the case of Althea therefore requires an endogenous institutionalist explanation.

\section{Monitoring mission in Aceh}

The EU-led Aceh Monitoring Mission (2005-2006) was concerned with the implementation of a peace agreement between the Government of Indonesia and the Free Aceh Movement. After several decades of conflict and failed peace talks, both parties contacted former Finnish President Martti Ahtisaari and asked him as a mediator for further negotiations. Before Ahtisaari could host the first round of peace negotiations, however, the devastating tsunami of 26 December 2004 hit the region and, in particular, the province of Aceh. It resulted in a temporary halt of hostilities (FT 2004) and a window of opportunity for a new peace agreement. One month after the tsunami, the first round of formal peace negotiations took place in Helsinki. The parties would eventually require five rounds, after which the EU together with the Association of Southeast Asian Nations (ASEAN) deployed some 250 monitors for a period of one-and-a-half year.

From the beginning, Ahtisaari was conscious of the fact that some sort of monitoring mechanism would be required in case of an eventual agreement. He thought, in this respect, that the EU's "involvement would be desirable" (quoted in Accord 2008). For symbolic reasons, the EU was the only party that could give credibility to the rebels and that would be acceptable to Indonesia (the $\mathrm{UN}$ had been compromised by events in East-Timor). Thus already after the first round of negotiations Ahtisaari called Solana, whom he knew personally well. Solana told him to "go ahead" (Merikallio 2008: 80) though naturally stating that it would finally be up to the member states to decide. In addition, Ahtisaari requested funding for his mediation activities from the European Commission (interview with Commission official, 2009). One of Ahtisaari's staff members 
suggested that this made the EU institutions shareholders of the project. It would "pave the way for ... European monitoring of the eventual peace agreement" (Herrberg, 2008). Needless to say, this was some useful external mobilization from Ahtisaari's side.

The second round of negotiations in Helsinki in February was successful, since the parties agreed to substantive talks. When talking to the press, Ahtisaari stated that both parties also recognised the need for outside monitors and that they would consider monitors of regional organizations (FT 2005). For this purpose, he noted, he had kept Solana informed (IHT 2005). In addition, Ahtisaari sent his military attaché to Brussels. This officer met with Pieter Feith, deputy Director-General External Relations in the Council Secretariat, and ten of Feith's staff members (Merikallio 2008). Ahtisaari himself had known Feith since the 1970s when they were both involved in UN matters. Feith showed an interest in the mission, yet it was "problematic for the EU to see how an unarmed monitoring mission [what Ahtisaari was proposing] could actually disarm" the Aceh rebels (ibid.: 82). Feith said that the EU would wait for the third round of negotiations before getting involved. What is interesting, however, is that EU planners through their networks were included at a far earlier stage than the member states. Even the planning team of the Finnish Ministry of Foreign Affairs got involved only in July 2005 (interview with Finnish official, 2009).

During the third round of talks in April 2005, several specific monitoring options were discussed with the parties, but they could not agree at that stage. After the negotiations, Ahtisaari left for Brussels (21 April) to brief the member states. He outlined how the EU could help and he stated that he had been in earlier contact with Solana (Merikallio 2008). While the reception was positive, Germany quickly pointed at the limited budgetary means of the EU and many member states were worried about the local security situation. Local EU ambassadors in Jakarta had been very critical indeed about a possible monitoring mission (ibid.). When the member states returned to the issue in May, they decided not yet to take an official stance, but to send observers to Helsinki. During the fourth round of talks in May, Feith briefed the negotiation parties and discussed with Ahtisaari the possibility of an interim presence between the signing of a peace agreement and the formal launch of the Aceh Monitoring Mission (ibid.). The EU sent a fact-finding mission to the region in June 2005.

During the final round of negotiations on 12-17 July 2005, Feith briefed the parties on the results of the fact-finding mission. He also outlined how the monitoring mission would look, which was presented to the parties as a fait accompli. The round of negotiations ended in the initialisation of the Memorandum of Understanding. The next day the Council of Ministers met and formally put the Aceh Monitoring Mission on the EU agenda by stating that "the EU was prepared, in principle, to provide observers" (18 July). Despite some serious negotiations over money, there was no way back. While only four member states wholeheartedly supported the operation (Grevi 2005), the rest had to go along. The EU ended up monitoring a peace agreement at the other side of the world for almost one-and-a-half year.

While the EU officials, including Solana and Feith, were pushing for this operation, they also had strong preferences to avoid a 'mission creep'. They were therefore very keen on getting the mandate they wanted. Within the context of the parameters set by the negotiating parties (unarmed monitors; no military peacekeepers; and preferably not too many monitors), Feith came up with the operations plan. He did not offer the negotiating parties nor the member states much room to further negotiate. They were effectively played out against each other. With regard to the mandate, Feith made sure that it was defined in a minimalistic way. The Aceh Monitoring Mission would only focus on security issues (monitoring disarmament and the withdrawal of Indonesian troops) and not on human rights issues. In terms of the timeframe of the mission, Feith suggested six months in order to get out as soon as possible. President Ahtisaari stated that this was too short. He accepted it nonetheless (interview in Accord 2008). As noted above, the eventual mission took significantly longer, but the EU kept the opportunity to move out on an earlier date.

To conclude on the Aceh Monitoring Mission, Solana and his officials played a leadership role during the agenda-setting phase. It was through their international contacts that the operation first came on the EU agenda. From them sending monitors all the way to South-East Asia was an 
excellent way of making CSDP a more global policy. The engagement with Aceh also showed that the EU could truly be a force for good. The EU officials used their almost exclusive contacts with the negotiating team of Ahtisaari to create several fait accomplis by raising external expectations. This unique position also gave them the opportunity to create a mandate that they wanted. Finally, once again, EU officials strategically alternated between political and bureaucratic venues. While most issues were settled at a lower bureaucratic level during fact-finding missions and with in the Council Secretariat, Solana on several occasions used his leverage with the national ambassadors and ministers in the Council.

\section{Military operation EUFOR in Chad and the Central African Republic}

In 2007-2008, the EU sent a 3700-troops strong military operation to Eastern Chad and the Central African Republic to provide security to some 250,000 refugees and 185,000 internally displaced people (International Crisis Group 2008). Many of these refugees were fleeing from conflict in the Darfur region of neighbouring Sudan. The EU military operation was initially not foreseen. From 2006, the UN had been planning a multidimensional presence, which would carry out humanitarian tasks, train local police, and consist of a military component to provide basic security. At a very advanced stage, Chadian President Idriss Déby made, however, clear that the military component would not be welcome in his country for reasons of sovereignty (see also UN S/2007/488). This eventually created the rationale for the EU to send troops instead.

Nicolas Sarkozy won the French Presidential elections and appointed Bernard Kouchner as his foreign minister in May 2007. Kouchner, in turn, noted that Darfur would be on his priority list (AFP 2007). He immediately convened a meeting to discuss the local situation and he advocated humanitarian corridors, no fly zones, mobilizing the EU, and looking into securing the border regions in Chad and the Central African Republic. France communicated these points to EU partners and requested an options paper before the next Council meeting in June (interview with Council Secretariat official, 2009). In addition, France invited a delegation of EU officials to its military headquarters in Paris at the end of May. The purpose of this meeting was to come up with a comprehensive plan (interview with EU official, 2009). Few people in Brussels knew about this meeting and the EU officials were told not to discuss it with anybody else. While the content of this meeting was preliminary, it again shows the early involvement of the EU officials in agenda-setting.

The desire to do something about the situation in Darfur did not take off immediately. Germany, which had at the time the rotating EU Presidency, was unenthusiastic (Berg 2009). Kouchner nonetheless went ahead. On 10 June, he bilaterally met with Déby. A delegation from the UN Security Council was visiting Chad at the same time to discuss the multidimensional presence. This delegation was told by the Chadian Foreign Minister that "following discussions with Mr. Kouchner the President had agreed, in principle, to the deployment of an international military presence in eastern Chad composed of French and other European Union forces" (UN S/2007/488, article 25). The UN delegation also learnt from Chadian officials that "a United Nations military presence was not favoured by the Chadian Government, although it could eventually be discussed as a second phase of a United Nations deployment" (ibid., article 23). Thus, the idea of a bridging operation where the EU would initially be in charge of the military component and prepare the ground for the UN gradually took shape already at that early stage.

The incoming Portuguese Presidency was more enthusiastic about the Chadian adventure than Germany and the process started moving in July 2007. In an early document on the timeframe of the planning of the operation, EU officials made clear that the Council could approve the operations plan - thus effectively launching the operation - during its meeting in October (interview with national official, 2009). Some of the member states were less in a hurry. They tasked EU officials to draft a joint options paper to be presented to the Council. The options paper of 13 July 2007 was an opportunity for EU officials to "[kill] the stupid ideas" (EU officials quoted in Mattelaer 2008: 14) and to come up with a more realistic plan. The humanitarian corridors and the no fly zone, as suggested by Kouchner, went directly off the table. The only feasible thing for the 
EU to do was to "close the two backdoors in order to avoid spillover in Chad" (interview with national official, 2009). Based on the paper, the Council gave the planning authority to the EU officials on 23 July.

French and EU planners worked out their plans over the summer of 2007. Apart from the focus on Eastern Chad and the concept of a one-year bridging operation, the mission was framed as an humanitarian operation that would provide support to the activities of the UN. This was the only way for them to get sufficient support from the other EU member states (interviews with national officials, 2009-2010). Towards the end of the summer, EU officials undertook a fact-finding mission to the region. This raised external expectations about EU action. Moreover, important details about the operation were leaked to the the French newspaper Le Figaro (interview with national official, 2009). This again triggered expectations. Finally, French and EU officials pushed through the Crisis Management Concept, which is the first formal document towards an eventual operation. With these worked out plans, the external expectations, an operation framed in humanitarian terms, France and the EU officials approached the other member states in September 2007.

Despite these intense preparations, getting the other member states on board remained difficult (Dijkstra 2010b). Germany and the United Kingdom made directly clear that they would not be sending any troops. They subsequently quarrelled with France over the costs of the operation. Sweden, which was initially enthusiastic, decided to only send a small contingent. France therefore strongly had to lobby for troop contributions. This involved the French President having to make various phone calls to his counterparts. Eventually, Ireland decided to make a major contribution and to make the Operations Commander available. It thought that supporting the UN on the Darfur dossier was exactly the kind of action that the EU had to undertake (interview with national official, 2009). Framing had this been (partially) successful. Various other member states also stepped in, albeit with smaller contributions.

Solana and his EU officials played perhaps a smaller role in the agenda-setting phase of the Chad operation than in some of the other cases. France clearly took the lead. That having been said, the EU officials did provide substantial support and the necessary cover. From a counterfactual point of view, it would be hard to imagine that any member state (with the exception of Poland) would have sent troops if the EU officials, including those of the Commission, had not supported the operation. Moreover, EU officials certainly played a role in determining what type of operation would be acceptable and how to best frame the operation to convince skeptical member states. It is also worth noting that French and EU officials kept the other member states (particularly Germany) for a very long time away from planning and only involved them when much of the work had been done. External expectations had already been raised by then.

\section{Rule of law mission EULEX in Kosovo}

The EU launched its most ambitious civilian mission to date, the rule of law mission EULEX, in Kosovo in 2008. It consists of some 1500 European rule of law experts and another 1000 local officials. The operation supports local police, justice and custom authorities in capacity building and it also carries out a restricted number of executive functions. The agenda-setting of this operation was a long process. Following the NATO bombing campaign in 1999, the Kosovo war came to an end with the adoption of UN Security Council Resolution 1244. This resolution mandated an international security presence and an international civilian presence. The Kosovo Force (KFOR) of NATO became in charge of security, while the UN led the civilian presence through its Mission in Kosovo (UNMIK). The emphasis of UNMIK was to strengthen the authorities in Kosovo before final negotiations could start on the international status of Kosovo. The population, however, feared postponement of independence and in March 2004, large-scale riots broke out that led to the death of nineteen and left a thousand people injured (UN S/2004/348). Following these events, UN Secretary-General Kofi Annan ordered a review process.

The EU had always been a key actor in Kosovo. It therefore followed the riots closely and 
the member states sent Solana to the region on 24 March 2004. UNMIK was blamed for letting things run out of control and its leadership subsequently resigned. With the position vacant, Solana took the initiative and managed to get Søren Jessen-Petersen appointed. Jessen-Petersen had been Solana's envoy in Macedonia. After his appointment to UNMIK, he took his seconded EU officials with him. The impression of Jessen-Petersen and his team was that "there was a complete lack of confidence about the United Nations" (interview with UN official, 2010). He therefore launched a series of informal discussions at the end of 2004 on the future arrangements of Kosovo. There was a clear agreement amongst these actors that "the UN had to reduce it presence and that the EU should raise its profile" (ibid.). UNMIK would hand over most tasks in the area of rule of law to the local authorities and the EU would take over some of the residual tasks. These discussions were useful, "because it became over time conventional wisdom that the European Union would go in. It started to send experts to meetings to see what was necessary" (ibid.).

As part of this review process, Jessen-Petersen naturally visited the Council for an exchange of views (21 February 2005). The member states noted that since the Thessaloniki European Council had reaffirmed the 'European perspective' of the Western Balkans, the EU would have to play a major role in any discussions concerning status. They thus "invited the [High Representative] and the Commission ... to examine with the United Nations and other relevant players what might be the future contribution of the European Union to the efforts of the international community in Kosovo ... and to report back to it on this" (Council 2005: 12). Solana and Enlargement Commissioner, Olli Rehn, drafted a joint report on the Future EU Role and Contribution in Kosovo (13 June 2005). ${ }^{4}$ The main strength of this report was in the process: the Commission and the Council Secretariat had a common vision on the future course of Kosovo. It created a precedent for future cooperation, although one official noted that "Rehn co-signed the papers ... the political drive was from [Solana]" (interview with Commission official, 2009).

The content of this report is noteworthy, because it established the main guidelines for the eventual EU rule of law mission (EULEX). Firstly, it stated that "the future international civilian presence could take the form of an international office with an important EU component but cannot be EUMIK". The role of UNMIK had been compromised by the events in March 2004 and the EU wanted to make a fresh start. Moreover, the EU was not willing to take over the all-encompassing mandate of UNMIK, but rather focus on a few specific tasks. The report thus argued, secondly, that "core areas will be the protection of minorities and the rule of law (police and justice)". The Council welcomed the report (13 June 2005), but did not take further action.

The negotiations on the future status of Kosovo started after the appointment of Ahtisaari as UN Special Envoy on 24 October 2005. The work of Ahtisaari was not concluded until March 2007, but the EU was closely involved. Importantly, on 6 December 2005, Solana and Rehn published a second joint report. This report reiterated that, regardless of its future status, Kosovo was in need of some international presence and that the EU would play a leading role. Yet again it stated clearly that the future international civilian presence would not be EUMIK. In line with the previous report, police and rule of law was highlighted as a priority area. Therefore, "contingency planning for a possible ESDP mission on police and rule of law should start" (Solana/Rehn 2005: 2).

The member states agreed with this conclusion and mandated an EU fact-finding mission (19-27 February 2006). The conclusion of this fact-finding mission was that further planning was necessary. Thus, it advised to the member states to set up a permanent Planning Team in Kosovo to "ensure that EU decision-making could be based on a solid and well analysed basis that is in step with the future status process" (2006/304/CFSP, preambular paragraph 10). The Planning Team was established on the ground in May 2006. Its legal basis carefully noted that it would not prejudge any subsequent decision by the Union to launch an CSDP operation, but the mission was already clearly beginning to take shape. The Planning Team stayed on the ground until the much-delayed start of the EULEX mission in July 2008.

\footnotetext{
$4 \quad$ This report and subsequent reports by Solana and Rehn are not publicly available, but a summary, from which this
} dissertation quotes, can be found online at http://www.consilium.europa.eu/solana. 
What was important about the agenda-setting of EULEX was that EU officials planned the mission under the assumption that there would be a final settlement on the political status of Kosovo. This turned out to be an unrealistic assumption (Dijkstra 2011), but it allowed Solana and his officials to move ahead with the mission. Given that the EU member states were divided on the political status of Kosovo, the EU officials intentionally avoided to enter into this political debate. Yet while they was planning the technical EULEX mission, it became common wisdom over time that the EU would launch a rule of law mission.

To conclude on EULEX, it is clear that Solana acted with considerable foresight. As he had been the NATO Secretary-General at the time of the Kosovo campaign, he obviously had unrivalled expertise and knowledge about the dossier. Following the March 2004 riots, he strategically started to plan for an EU presence in cooperation with like-minded officials. Rehn and Jessen-Petersen have been mentioned, but there was also his informed Western Balkans Director, Stefan Lehne, and the connection with Ahtisaari. Solana also ensured that the dossier was once again kept out of the hands of the member states and he helped set the important parameters around which EULEX was eventually conceived. Finally, the process itself was important. The agenda-setting phase was very long and due to the activity of EU officials over time, there was clear external expectations that the EU would be involved, one way or another, after independence.

\section{CONCLUSION}

This article has presented an institutional perspective on agenda-setting in CSDP. It has argued that Solana and his civil servants possessed considerable bureaucratic resources resulting from their institutional position in policy-making - information on the state-of-play, an early mover advantage and international networks. This allowed them to push for new operations, which was in line with their bureaucratic interest. It helps to explain why the EU launched as many as twenty-eight crisis management missions in the first decade of CSDP.

When studying the individual operations from an empirical perspective, it is interesting to note that agenda-setting in all cases played at both the political and administrative levels. In the case of Bosnia, Solana pushed for a European Council endorsement and then had his civil servants work out plans at the administrative level. During the Aceh Monitoring Mission, agenda-setting was kept at an administrative level, only for Solana to present it eventually to the member states as a fait accompli. For Chad, the French Presidential elections created momentum, but significant work was also done by the EU officials. In Kosovo, the events of March 2004 equally were a defining political event, but Solana and his officials also gradually increased momentum for the EULEX Kosovo operation.

EU officials teaming up with like-minded actors during the agenda-setting phase was a determining factor in all operations as well. In Bosnia, Solana worked with France and the United Kingdom and formed a core group to get this operation off the ground. In Aceh, EU officials intensively worked together with the team of Ahtisaari. Many member states were deliberately excluded from the negotiations in Helsinki to avoid interference. For Chad, France found natural allies in the EU officials. Most of the other member states were excluded and only started to seriously discuss the operation in September/October 2007. For Kosovo, Solana worked with likeminded actors as well, including actors outside the EU. In the cases, the involvement and exclusion of certain actors was thus important for the agenda-setting of the operations. The core group, which always involved the EU officials, was often better prepared than the opposing EU actors. This gave momentum for decision-making (see Howorth 2012).

Solana and his officials also significantly contributed to the framing of the missions. In the case of Bosnia, Solana partially achieved to define the operation as "new and distinct" with a strong focus on the fight against organized crime. For Aceh, EU officials played the negotiating parties and the member states out against each other. Moreover, they focussed on security issues rather than on human rights to lower the risk of failure. In the case of Chad, EU officials used the initial 
options paper to get attention squarely on eastern Chad and the Central African Republic. This was feasible, other suggestions were non-starters. For EULEX Kosovo, Solana was outspoken in the framing of the mission. It was not going to be a continuation of UNMIK. This became widely accepted and had all sorts of consequences for the mission. Part of the ability to frame CSDP operations was certainly due to the political leadership and experience of Solana as an individual.

When generalizing the findings across the case studies, it is thus evident that institutional agenda-setting strategies were consistently used by Solana and his officials. Excluding member states, external mobilisation and the creation of expectations, the strategic use of bureaucratic and political venues, and the framing of CSDP operations came back time and again. This finding fits in with accounts of (bureaucratic) leadership in other international organizations (e.g. Barnett and Finnemore 1999, 2004; Hendrickson 2006; Biermann and Siebenhüner 2009). It does raise the question why the member states have let Solana and his officials get away with it. Needless to say, the number of new CSDP operations has declined rapidly since 2009, because member states have made their objections known at much earlier stages in the process.

It is important to acknowledge that this article has only empirically studied cases in which agenda-setting actually took place. It is also important for scholars to study non-cases. This has been a traditional weakness of the agenda-setting in the EU literature. After all, non-cases typically leave little empirical trace. This counts, in particular, for non-decision cases (Bachrach and Baratz 1962), in which certain issues are never discussed due to an (elitist) consensus on the status quo. There exist, of course, also several instances where CSDP operations were more-or-less seriously discussed. Relevant examples are Darfur, Sri Lanka, Libya, and above all Congo in 2008 (Gowan 2009). These cases require further analysis if we are to answer why and where the EU deploys its operations.

What are the consequences of the Lisbon Treaty, one may also ask, for agenda-setting in the field of CSDP. An argument can be made that with the External Action Service, Brussels now has even more bureaucratic resources available for agenda-setting purposes (e.g. Vanhoonacker and Pomorska 2013). That having been said, with the appointment of Ashton, the EU has also lost the considerable political and personal expertise as well as the international networks of Solana. Moreover, CSDP operations formed the main raison d'être of the foreign policy services in the Council Secretariat. Deploying CSDP operations on the ground gave them political leverage vis-àvis the Commission. This rationale is gone since the Lisbon Treaty, which merged the various Commission and Council Secretariat services thereby decreasing bureaucratic politics. It is thus not surprising that Ashton has paid much less attention to crisis management (ibid.). It is worth noting though that at the time of writing, several small new CSDP operations were launched. ${ }^{5}$ The input seemed to have come from the EU civil servants in order to keep CSDP alive.

\section{Acknowledgements}

An earlier version of this article was presented during a conference at the University of Salford on 27-28 January 2011. The author would like to acknowledge all participants for their comments. He would furthermore like to acknowledge Benjamin Pohl and the three anonymous referees. The final version of this article was submitted when the author still worked at Maastricht University.

\section{References}

Accord (2008) Delivering peace for Aceh: an interview with President Martti Ahtisaari. Available

\footnotetext{
In 2012, the EU launched an operation with 80 staff members to support the fight against organized crime and terrorism in the Sahel (EUCAP SAHEL Niger), it sent 64 officials to South Sudan to bring airport security in Juba to international standards (EUAVSEC South Sudan), and 175 people to the Horn of Africa to help states in the region improve their capability to govern their territorial waters in the fight against piracy (EUCAP NESTOR).
} 
at: www.c-r.org/accord-article/delivering-peace-aceh-interview-president-martti-ahtisaari (accessed 16 July 2012).

Agence France-Presse (2007) Darfur to top agenda for French FM Kouchner. 18 May.

Albright M (1998) The Right Balance Will Secure NATO's Future. Financial Times, 7 December.

Bachrach P and Baratz M (1962) The Two Faces of Power. American Political Science Review 56(4), pp. 947-952.

Barnett M and Finnemore M (1999) The Politics, Power, and Pathologies of International Organizations. International Organization 53(4), pp. 699-732.

Barnett M and Finnemore M (2004) Rules for the World: International Organizations in Global Politics. Ithaca: Cornell University Press.

Baumgartner F and Jones B (1991) Agenda Dynamics and Policy Subsystems. Journal of Politics 53(4): 1044-1074.

Beach D (2004) The unseen hand in treaty reform negotiations: the role and influence of the Council Secretariat. Journal of European Public Policy 11(3): 408-439.

Beach D (2005) The Dynamics of European Integration: Why and when EU institutions matter. Basingstoke: Palgrave Macmillan.

Berg P (2009) EUFOR Tchad/RCA: The EU Serving French Interests. In: Asseburg M and Kempin R (eds) The EU as a Strategic Actor in the Realm of Security and Defence. Berlin: Stiftung Wissenschaft und Politik, pp. 57-69.

Bertin T (2008) The EU Military Operation in Bosnia. In: Merlingen M and Ostrauskaite R (eds) The European Security and Defence Policy: An Implementation Perspective. London: Routledge, pp. 61-77.

Biermann F and Siebenhüner B (eds) (2009) Managers of Global Change The Influence of International Environmental Bureaucracies. Cambridge: MIT University Press.

Cameron F (2007) An Introduction to European Foreign Policy. London: Routledge.

Cascone G (2008) ESDP Operations and NATO: Co-operation, Rivalry or Muddling-through? In: Merlingen M and Ostrauskaite R (eds) The European Security and Defence Policy: An Implementation Perspective. London: Routledge, pp. 143-158.

Chesterman S (ed.) (2007) Secretary or General? The UN Secretary-General in World Politics. Cambridge: Cambridge University Press.

Christiansen T (2002) Out of the Shadows: The General Secretariat of the Council of Ministers. Journal of Legislative Studies 8(4): 80-97.

Christiansen T and Vanhoonacker S (2008) At a Critical Juncture? Change and Continuity in the Institutional Development of the Council Secretariat. West European Politics 31(4): 751-770.

Cobb R, Ross JK and Ross M (1976) Agenda Building as a Comparative Political Process. 
American Political Science Review 70(1): 126-138.

Council (2003) Presidency Conclusions, 24 February.

Council (2005) Presidency Conclusions, 21 February.

Dijkstra H (2008) The Council Secretariat's Role in the Common Foreign and Security Policy. European Foreign Affairs Review 13(2): 149-166.

Dijkstra H (2010a) Explaining variation in the role of the EU Council Secretariat in first and second pillar policy-making. Journal of European Public Policy 17(4): 527-544.

Dijkstra H (2010b) The Military Operation of the EU in Chad and the Central African Republic: Good Policy, Bad Politics. International Peacekeeping 17(3), 395-407.

Dijkstra H (2011) The Planning and Implementation of the Rule of Law Mission of the European Union in Kosovo. Journal of Intervention and Statebuilding 5(2), pp. 193-210.

Dijkstra H (2012) The influence of EU Officials in European Security and Defence. European Security, DOI: 10.1080/09662839.2012.667805.

European Council (2002) Presidency Conclusions, 12-13 December.

European Security Review (2003) US blocks early EU takeover of SFOR, 18(9).

Financial Times (2003) US puts off EU takeover of Bosnia mission, 4 June.

Financial Times (2004) Relief work may aid peace moves in conflict areas, 29 December.

Financial Times (2005) Aceh peace talks agree August target date for deal, 24 February.

Giegerich B, Pushkina D and Mount A (2006) Towards a Strategic Partnership? The US and Russian Response to the European Security and Defence Policy. Security Dialogue 37(3): 385-407.

Gowan R (2009) The Case of the Missing Battlegroups: Is EU-UN Military Cooperation in Decline? Studia Diplomatica: The Brussels Journal of International Relations 62(3), pp. 53-60.

Grevi G (2005) The Aceh Monitoring Mission: Towards Integrated Crisis Management. In: Braud P and Grevi G (eds) The EU Mission in Aceh: Implementing Peace. Chaillot Paper 61, Paris: EU Institute for Security Studies.

Hawkins D et al. (eds) (2006) Delegation and Agency in International Organizations. Cambridge: Cambridge University Press.

Hendrickson R (2006) Diplomacy and War at NATO: The Secretary General and Military Action after the Cold War. Columbia: University of Missouri Press.

Herrberg A (2008) The Brussels "backstage" of the Aceh peace process. In: Aguswandi and Large J (eds) Reconfiguring politics: the Indonesia - Aceh peace process. Accord. Available at: www.cr.org/accord-article/brussels-backstage-aceh-peace-process (accessed 16 July 2011).

Hill C (1993) The Capability-Expectations Gap or Conceptualizing Europe's International Role. 
Howorth J (2012) Decision-Making in Security and Defence Policy: towards supranational intergovernmentalism? Cooperation and Conflict, this issue.

International Crisis Group (2008) Chad: A New Conflict Resolution Framework. Africa Report 144, Brussels: International Crisis Group.

International Herald Tribune (2005) Jakarta is upbeat on Aceh peace; Both sides maneuver around critical issue, 25 February.

Jordan R (1979) Political Leadership in NATO: A Study in Multinational Diplomacy. Boulder: Westview Press.

Kingdon J (1984) Agendas, Alternatives, and Public Policies. Boston: Little, Brown and co.

Leakey D (2006) ESDP and Civil/Military Cooperation: Bosnia and Herzegovina, 2005. In: Deighton A and Maurer V (eds) Securing Europe? Implementing the European Security Strategy. Zürich: Swiss Federal Institute for Technology, pp. 59-68.

Mace C (2004) Operation Concordia: developing a 'European' approach to crisis management? International Peacekeeping 11(3): 474-490.

Majone G (ed.) (1996) Regulating Europe. London: Routledge.

Manners I (2002) Normative Power Europe: A Contradiction in Terms? Journal of Common Market Studies 40(2): 235-258.

Mattelaer A (2008) The Strategic Planning of EU Military Operations-The Case of EUFOR Tchad/RCA. IES Working Papers 5, Brussels: Institute for European Studies.

Mérand F, Hofmann S and Irondelle B (2010) Transgovernmental Networks in the European Security and Defense Policy. European Integration Online Papers 14.

Mérand F, Hofmann S and Irondelle B (2011) Governance and State Power: A Network Analysis of European Security. Journal of Common Market Studies 49(1): 121-147.

Merikallio K (2008) Making Peace: Ahtisaari and Aceh. Helsinki: WSOY.

Peters G (2001) Agenda-setting in the European Union. In: Richardson J (ed.), European Union: Power and Policy-making. London: Routledge, pp. 77-94.

Pollack M (1997) Delegation, agency, and agenda-setting in the European Community. International Organization 51(1): 99-134.

Pollack M (2003) The Engines of European Integration: Agency, Delegation, and Agenda Setting in the EU. Oxford: Oxford University Press.

Princen S (2007) Agenda-setting in the European Union: a theoretical exploration and agenda for research. Journal of European Public Policy 14(1): 21-38.

Princen S (2009) Agenda-Setting in the European Union, Basingstoke: Palgrave. 
Princen S (2011) Agenda-setting Strategies in EU Policy Processes. Journal of European Public Policy, 18(7), pp. 927-943.

Princen S and Rhinard M (2006) Crashing and creeping: agenda-setting dynamics in the European Union. Journal of European Public Policy 13(7): 1119-32.

Reichard M (2006) The EU-NATO Relationship: A Legal and Political Perspective, Aldershot: Ashgate.

Robertson G, Papandreou G and Solana J (2003) Press Conference following the NATO-EU Meeting in Madrid, 3 June. Available at: http://www.nato.int/docu/speech/2003/s030603i.htm (accessed 16 July 2012).

Tallberg J (2003) The agenda-shaping powers of the EU Council Presidency. Journal of European Public Policy 10(1): 1-19.

Tallberg J (2006) Leadership and Negotiation in the European Union. Cambridge: Cambridge University Press.

Schattschneider E (1960) The Semisovereign People: A Realist's View of Democracy in America. New York: Holt, Rinehart and Winston.

Vanhoonacker S, Dijkstra H and Maurer H (2010) Understanding the Role of Bureaucracy in the European Security and Defence Policy: The State of the Art. European Integration Online Papers 14(1), pp. 1-33.

Vanhoonacker S and Pomorska K (2013) The European External Action Service and Agendasetting in European Foreign Policy. Journal of European Public Policy 20, forthcoming.

Waltz K (1979) Theory of International Politics. New York: McGraw-Hill.

Woodbridge J (2002) Ready and willing to take charge in the Balkans? European Security Review 14: 3-4. 